4 O'Tauma LA, Kirkman HN, James PM. Raised intracranial pressure after hyperalimentation. Lancet 1973 ;ii:1101.

5 Saxena VK, Heilpern RJ, Murphy SF. Pseudomotor cerebri. A complication of parenteral hyperalimentation. $\mathcal{f} A M A$ 1976;235:2124.

(Accepted 17 fune 1982)

Nuffield Department of Surgery, University of Oxford, John Radcliffe Hospital, Oxford OX3 9DU

R G SOUTER, MD, FRCs, clinical lecturer in surgery

A MITCHELL, BM, FRCS, clinical lecturer in surgery

\section{Pleurisy and pulmonary granulomas after treatment with acebutolol}

Many patients currently take beta-blockers to control hypertension or angina and such medication is often continued for years. Side effects are uncommon but reports of ocular, cutaneous, and serosal damage led to the withdrawal of the cardioselective beta-blocker practolol from long-term use. We report a case in which treatment with acebutolol was followed by recurrent attacks of pleurisy necessitating withdrawal of the drug.

\section{Case report}

A 47-year-old woman presented with a three-month history of intermittent pleuritic chest pain. The bouts of pain each lasted a few days but the site varied; for the last two weeks she had had a non-productive cough. She was not short of breath and was otherwise well with no previous history of respiratory disease. Two years before, she had been found to be hypertensive and had taken acebutolol (200 mg daily) and xipamide (20 mg daily) regularly since then.

Examination showed no sign of fever, clubbing, or cyanosis. A prominen pleural rub was heard in the left axilla and at other times rubs were heard in other areas of both lung fields. No other abnormalities were evident. Investigation showed a normal white cell count and differential but the erythrocyte sedimentation rate was $70 \mathrm{~mm}$ in the first hour. Antinuclear and rheumatoid factors were not detected and serum immunoglobulin and DNA-binding antibody values were normal. Sputum and urine samples were sterile and acid-fast and alcohol-fast bacilli were not present; results of viral studies were negative. Peak expiratory flow rate was $4801 / \mathrm{min}$ forced expiratory volume in one second $2 \cdot 21$ (95\% predicted), and vital capacity $2 \cdot 71(100 \%$ predicted). Repeated chest $x$-ray pictures were normal as was a ventilation-perfusion lung scan. $X$-ray computed tomography of the chest showed irregular subpleural densities at the lung bases, particularly on the right. These were thought to be intrapulmonary, though there was also patchy pleural thickening. Schirmer's test gave an abnormal result, the right eye producing $10 \mathrm{~mm}$ saturation at five minutes and the left eye $4 \mathrm{~mm}$ (normal $>15 \mathrm{~mm}$ ). Rose bengal staining was negative.

Disabling bouts of pleurisy for five months eventually necessitated an open-lung biopsy of the right lower lobe, disclosing patchy fibrosis and slight thickening of the visceral pleura. Histological studies showed granulomas in the lung with fibrosis; the granulomas were unlike those of sarcoidosis and contained scattered groups of degenerate eosinophils. Angiitis was not present and the tissue was thought to show an inflammatory condition. There was no evidence of fungal or tuberculous infection and cultures grew no pathogens.

Acebutolol was withdrawn and cyclopenthiazide substituted for xipamide. Over the next nine months the attacks of pleural pain became less frequent, the rubs disappeared, the erythrocyte sedimentation rate fell to $5 \mathrm{~mm}$ in the first hour, and a repeat Schirmer's test gave values of $38 \mathrm{~mm}$ and $28 \mathrm{~mm}$ at five minutes for the right and left eyes respectively. Follow-up pulmonary function tests gave normal values and the patient became asymptomatic.

\section{Comment}

Despite widespread use, there are only sporadic reports of oculomucocutaneous side effects from beta-blockers other than practolol. With that drug patients developed keratoconjunctivitis sicca, corneal opacities, rashes, and serositis. ${ }^{1}$ Included in this last category were cases of "plastic peritonitis" and pleurisy ${ }^{1-3}$ and one report of fatal interstitial pulmonary fibrosis. ${ }^{4}$ The possibility remains that other drugs of this class might cause similar reactions.

Our patient suffered severe pleurisy necessitating a diagnostic thoracotomy. When acebutolol was withdrawn her symptoms gradually disappeared and there was no obvious cause apart from a drug reaction. It seems unlikely that xipamide was responsible, and it is worth noting that acebutolol resembles practolol more closely than any other beta-blocker, being cardioselective, an anilide, and havin partial agonist activity. ${ }^{5}$ The manufacturers of acebutolol and the Committee on the Safety of Medicines have had no reports of pleuris or pulmonary granulomas associated with the drug.

We thank Professor $\mathrm{H}$ Spencer for help in interpreting the lung biopsy findings.

1 Wright P. Untoward effects associated with practolol administration oculomucocutaneous syndrome. Br Med f 1975; i :595-8.

${ }^{2}$ Marshall AJ, Baddeley H, Barritt DW, et al. Practolol peritonitis. $Q \overrightarrow{\aleph^{\circ}}$ Med 1977;46:135-49.

${ }^{3}$ Mackay AD, Axford AT. Pleural effusions after practolol. Lancet $1976 \overbrace{}^{\circ}$ i :89.

${ }^{4}$ Erwteman TM, Braat MCP, Van Aken WG. Interstitial pulmonar fibrosis: a new side effect of practolol. $\mathrm{Br}$ Med $\mathcal{F} 1977$;ii :297-8.

${ }^{5}$ Cruickshank JM. The clinical importance of cardioselectivity and lipo philicity in betablockers. Am Heart f 1980;100:160-78.

(Accepted 17 June 1982)

Department of Medicine, St James's University Hospital, Leed? LS9 7TF

G M WOOD, BSC, MRCP, registrar in medicine

R P BOLTON, MA, MRCP, lecturer in medicine

M F MUERS, DPHIL, MRCP, consultant physician

M S LOSOWSKY, MD, FRCP, professor of medicine

\section{Fatal acute immune haemolytic anaemia caused by nalidixic acid}

Haemolytic anaemia in subjects with glucose-6-phosphate-dehydrogenase deficiency is the only reported haematological complication of treatment with nalidixic acid. ${ }^{1}$ We describe the onset of fatal immunê haemolytic anaemia after administration of nalidixic acid.

\section{Case report}

A 74-year-old woman had a 10-year history of episodes of haemolyti市 anaemia. Results of direct Coombs test during each attack were positive?

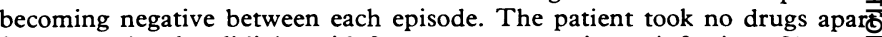
from occasional nalidixic acid for a recurrent urinary infection. She was admitted to the department of general medicine on 29 March 1980 with a haemolytic crisis. Laboratory tests showed red cell count of $2.59 \times 10^{7} / \mathrm{R}$ haemoglobin concentration of $9.8 \mathrm{~g} / \mathrm{dl}$, mean cell volume $107 \mathrm{fl}$, leucocytes. $2 \cdot 7 \times 10^{5} / 1$, reticulocytes $8.4 \%$, total bilirubin $2.97 \mathrm{mg} / 100 \mathrm{ml}(51 \mu \mathrm{mol} / 1)$ direct Coombs test gave weakly positive results; serum lactate dehydro genase activity was $850 \mathrm{U} / 1$ and haptoglobin concentration less than $0.2 \mathrm{~g} / \mathrm{1}$. Tests for glucose-6-phosphate-dehydrogenase, sideraemia, transferrinaemia Waaler-Rose reaction, lupus erythematosus cells, antinuclear factors, complement fixation for Mycoplasma pneumoniae, osmotic fragility, and auto haemolysis gave negative results, as did $\mathrm{Ham}$-Crosby and Donath-Landsteine tests. The myelogram showed a pronounced erythropoiesis. Haemolysis was controlled with betamethasone.

On 17 April 1980 the patient complained of dysuria and pollakiuria an nalidixic acid was prescribed. After the first dose of $1000 \mathrm{mg}$ the patien? suffered a serious attack of intravascular haemolysis and died after a few hours despite high doses of steroids and a blood transfusion with compatible blood. The haemogram was illegible for autohaemolysis; result of indirect Coombs test was weakly positive and of the direct Coombs test strongl positive. It was impossible to determine the antibodies for autopanagglutinae tion of erythrocytes. Results of tests with monospecific sera showed a cleag positivity with anti IgG and anticomplement.

\section{Comment}

A positive result to the direct Coombs test in one of the earlieD haemolytic crises, negative results between attacks, and clearly positiv results during the terminal attack suggested a haemolytic anaemia of immunological pathogenesis. The absence of infection with $M P$ pneumoniae and of autoimmune diseases or underlying lympho proliferative disorders, together with a fatal intravascular haemolyti\& attack after administration of nalidixic acid points to a clear connection between drug and haemolysis. Retrospectively, we deduce that the previous haemolytic attacks were caused by nalidixic acid, which the 